Przegląd Narodowościowy / Review of Nationalities • nr 7/2017 • World of Slavs / Świat Słowian

DE DE GRUYTER

ISSN 2084-848X (print) • ISSN 2543-9391 (on-line) • DOI 10.1515/pn-2017-0017

\title{
Stanisław Potrzebowski, Słowiański ruch Zadruga, publishing house “Triglav", Szczecin 2016, pp. 216
}

Stanisław Potrzebowski, Słowiański ruch Zadruga, Wydawnictwo „Triglav", Szczecin 2016, ss. 216

Zadruga was a Slavic-national movement using today's terminology you could also call it an "identitarian" one. Officially, it appeared in 1937, when periodical "Zadruga”, which was published in 1937-1939, was issued for the first time. Despite not many members, this movement can be described as significant. Its creator - Jan "Stoigniew" Stachniuk created an original thought - a philosophical system called by him "Culturalism", or "evolutionary pantheism". The movement itself is also significant, because it is - next to the Christian, National Democratic nationalism - the second pillar of Polish nationalism, i.e. of a Slavic, neopagan character - in a word, "Zadrugian" character. The literature is still quite scarce, despite several book publications on the subject.

Stanislaw Potrzebowski has already been dealing with Zadruga for several decades, what you can learn from the Foreword. He received the $\mathrm{PhD}$ degree in Bonn in 1983. His dissertation was titled: Zadruga - Eine völkische Bewegung in Polen on Zadruga. His book Słowiański ruch Zadruga (Slavic movement Zadruga) is not so much a translation of the first work, but a new work written for the Polish readers.
Zadruga była ruchem o charakterze słowiańsko-narodowym - używając dzisiejszej nomenklatury można by ją nazwać również „tożsamościowym”. Oficjalnie zaistniała ona w 1937 r., gdy wydany został po raz pierwszy periodyk „Zadruga”, który ukazywał się w latach 1937-1939. Mimo niezbyt dużej liczebności członków, ruch ten można określić jako znaczący. Jego twórca Jan „Stoigniew” Stachniuk stworzył bowiem niezwykle oryginalną myśl - system filozoficzny zwany przez niego „kulturalizmem” czy też „panteizmem ewolucyjnym”. Sam ruch jest też o tyle znaczący, że stanowi - oprócz nacjonalizmu chrześcijańskiego, endeckiego - drugi pień polskiego nacjonalizmu, tj. o charakterze słowiańskim, neopogańskim - jednym słowem „zadrużnym”. Literatura przedmiotu jest cały czas dość skąpa, mimo kilku książkowych publikacji na ten temat.

Stanisław Potrzebowski tematem Zadrugi zajmuje się już kilkadziesiąt lat, o czym dowiedzieć się można z Przedmowy. Obronił doktorat w Bonn w 1983 r. pt. Zadruga - Eine völkische Bewegung in Polen na temat Zadrugi. Książka Słowiański ruch Zadruga jest nie tyle tłumacze- 
It was divided into four chapters, preceded by a foreword by the publisher and the author's preface. The first chapter deals with the predecessors of Zadruga, discusses its ideological inspirations. The second shows the circumstances of the movement and its development and history. The third shows the philosophy of the movement, its cosmology and philosophical anthropology. The fourth compares Zadruga with other similar intellectual and religious movements. The final part is the source annex in the form of article Nacjonalizm jest naszym światopogladem (Nationalism is our worldview) by Antoni Wacyk, which appeared in the monthly Zadruga in JuneJuly 1938, and a poem Hymn do Swaroga (Hymn to Svarog) by the same author. The whole has 216 pages.

It is really difficult to make an adequate assessment of the book by S. Potrzebowski. The difficulty in assessing stems from the fact that it is not known exactly how to classify this publication. In the preface of the publisher it is written that the book by S. Potrzebowski is a "scientific work in the field of the history of ideas" ${ }^{\prime}$. This thesis is debatable.

The publication is good in the substantive layer. The source material is relatively abundant and varied. The author uses both publications by Stachniuk, reports and other books referring in some way to Zadruga. The chapter on the history of the movement is undoubtedly interesting and contains a lot of interesting details from the life of its members and activities of Zadruga. Ideological convictions and philosophy

1 S. Potrzebowski, Słowiański Ruch Zadruga, Szczecin 2016, p. 5. niem tamtego dzieła, ile dziełem nowym napisanym z myślą o czytelniku polskim.

Została ona podzielona na cztery rozdziały, poprzedzone przedmową wydawcy i wstępem autora. Pierwszy traktuje o poprzednikach Zadrugi, omawia jego inspiracje ideowe. Drugi przedstawia okoliczności powstania ruchu i jego rozwój i historię. Trzeci ukazuje filozofię ruchu, jego kosmologię oraz antropologię filozoficzną. Czwarty porównuje Zadrugę z innymi, podobnymi ruchami intelektualnymi i religijnymi. Całość kończy aneks źródłowy w postaci zredagowanego przez Antoniego Wacyka artykułu pt. Nacjonalizm jest naszym światopogladem, który ukazał się w miesięczniku Zadruga z czerwca-lipca 1938 r., jak i wiersz Hymn do Swaroga tego samego autora. Całość ma 216 stron.

Doprawdy ciężko dokonać adekwatnej oceny książki S. Potrzebowskiego. Trudność w ocenie bierze się z tego, że nie wiadomo właściwie, $w$ jaki sposób zaklasyfikować tę publikację. W przedmowie wydawcy jest bowiem napisane, iż książka S. Potrzebowskiego to "naukowa praca z zakresu historii idei”" Teza ta jest dyskusyjna.

W warstwie merytorycznej publikacja jest dobra. Materiał źródłowy jest dość bogaty i zróżnicowany. Autor opiera się zarówno na publikacjach samego Stachniuka, opracowaniach, jak i innych książkach nawiązujących w jakiś sposób do Zadrugi. Rozdział o historii ruchu jest niewątpliwie ciekawy i zawiera sporo interesujących szczegółów z życia jego członków

1 S. Potrzebowski, Słowiański Ruch Zadruga, Szczecin 2016, s. 5. 
of Culturalism is presented in a satisfactory and comprehensive way. Quite glaring errors in the workshop, as well as some controversial thesis, sometimes having no basis in facts are the downside to the book.

One of them is a clear placing the Zadruga movement to the right wing - implicitly expressed on page 42 and explicitly on page 166. Comparing Zadruga to the Ludendorffs' Movement, the author states: Both are classified as non-Christian extreme right wing, and that's an exception to the right side of the nationally tuned movements ${ }^{2}$. What does "are classified" mean? Who exactly classifies them in this way? The author supports this thesis with nothing. He gives no source, no names, no article or publication that would confirm it.

"It is difficult [...] to assign Stachniuk, even on the basis of this first book [Kolektywizm a naród (Collectivism and the nation) - ed. P.B.], leftist views, as he expressed in it dismissively, and at least reluctantly about the guru of all the left wing - Marx"3 - says the author. This conclusion is drawn from that quote from the book by Stachniuk Kolektywizm a naród. I quote it in full:

Surely we can say that all the principles of Marxism were formulated much earlier than we saw them in "Capital". The principle of materialistic conception of history was already developed as a complete system in France by Pecquer. The theory of overvalue can sought its father in Tompson, and the famous theory

\footnotetext{
2 Ibidem, p. 166.

${ }^{3}$ Ibidem, p. 42.
}

i działalności Zadrugi. Podłoże ideowe i filozofia kulturalizmu jest przedstawiona w zadowalający i wyczerpujący sposób. Minusem książki zaś są dość rażące błędy $\mathrm{w}$ warsztacie, jak i pewne kontrowersyjne tezy, czasem niemające oparcia w faktach.

Jedną z nich jest jednoznaczne zaliczanie ruchu Zadruga do prawicy - wyrażone implicite na stronie 42 i explicite na stronie 166. Porównując Zadrugę do Ruchu Ludendorffów, autor stwierdza: „Oba są zaliczane do skrajnej niechrześcijańskiej prawicy, a to już stanowi wyjątek na prawej stronie narodowo nastrojonych ruchów"2. Co to znaczy „są zaliczane”? Kto konkretnie je w ten sposób zalicza? Autor niczym nie podpiera tej tezy. Nie podaje żadnych źródeł, żadnych nazwisk, żadnego artykułu ani publikacji, która by to potwierdzała.

„Trudno [...] przypisywać Stachniukowi, nawet na podstawie tej pierwszej książki [Kolektywizm a naród - przyp. P.B.], poglądy lewicowe, skoro wyrażał się w niej lekceważąco i co najmniej niechętnie o guru wszelkiej lewicy - Marksie"3 - stwierdza autor. Wniosek ten wysnuwa $\mathrm{z}$ tego oto cytatu Stachniuka z książki Kolektywizm a naród. Przytaczam owy cytat w całości:

$\mathrm{Z}$ całą pewnością możemy rzec, iż wszystkie zasady marksizmu zostały znacznie wcześniej sformułowane, niż je ujrzeliśmy w „Kapitale". Zasada materjalistycznego pojmowania dziejów została rozwinięta jako cały system we Francji już przez Pecquera. Teorja nadwartości swego ojca upatrywać może w Tompsonie, zaś sławetna teorja walki klas w nadzwyczaj przejrzystej formie jest spotykana u Blanc'a ${ }^{4}$.

\footnotetext{
${ }^{2}$ Ibidem, s. 166.

3 Ibidem, s. 42.

${ }^{4}$ J. Stachniuk, Kolektywizm a naród, http:// toporzel.republika.pl/teksty/kolpol.html [dostęp: 29.10.2016].
} 
of the class struggle in an extremely clear form is common in Blanc's works ${ }^{4}$.

The author reminds of the fact that other economists (e.g. De Greef, Brooks Adams) had previously talked about the primacy of existence over consciousness.

Firstly, the given quote (or the views of these economists), however, in no way shows that Stachniuk had a disrespectful and unfriendly attitude to Marx. Borrowing and reuse of earlier thinkers has also been the practice followed since the beginning of the history of human thought. Secondly, the quote (or any book by Stachniuk) does not show that Stachniuk "was hardly leftist" (This of course also depends on how we use the definition of the term "left"). Potrzebowski seems not to realize at all, that leftism is not synonymous with Marxism (the example could be Fabianism). Although undoubtedly the movement Zadruga was not in any way Marxist (including rejection of the Marxist thesis of the primacy of existence over consciousness, philosophical materialism, internationalism), but it had a lot of elements generally considered leftist, such as anticapitalism, postulating a centrally planned economy, the postulate of a classless society, criticism of traditionalism, criticism of the Catholic Church and Catholicism, praise of eugenics, etc. What's interesting, although Potrzebowski often brings Heroiczna wspólnota narodu, he never mentions that Stachniuk almost fully accepts the theory of imperialism developed by W. Lenin and R. Luxemburg, which

${ }^{4}$ J. Stachniuk, Kolektywizm a naród, http://toporzel.republika.pl/teksty/kolpol.html [access on: 29.10.2016]
Autor przypomina również to, iż inni ekonomiści (np. De Greef, Brooks, Adams) wcześniej już mówili o prymacie bytu nad świadomością. Z przytoczonego cytatu (ani poglądów wspomnianych ekonomistów) jednak w żaden sposób nie wynika, że Stachniuk miał lekceważący i niechętny stosunek do Marksa - to po pierwsze. Zapożyczanie i ponowne używanie tez wcześniejszych myślicieli jest praktyką stosowaną od początku historii ludzkiej myśli. Po drugie, z cytatu (ani żadnej książki Stachniuka) nie wynika to, że Stachniuka „trudno posądzać o poglądy lewicowe” (to oczywiście również zależy od tego, jaką stosujemy definicję terminu „lewica”). Potrzebowski zdaje się nie zdawać w ogóle sprawy, że lewicowość nie jest tożsama z marksizmem (przykładem chociażby fabianizm). Choć bez wątpienia ruch Zadrugi nie miał charakteru marksistowskiego (m.in. brak akceptacji dla marksowskiej tezy o prymacie bytu nad świadomością, filozoficznego materializmu, internacjonalizmu), to występowało w nim jednak sporo elementów uważanych powszechnie za lewicowe, jak choćby antykapitalizm, postulowanie gospodarki centralnie planowanej, postulat społeczeństwa bezklasowego, krytyka tradycjonalizmu, krytyka Kościoła katolickiego i katolicyzmu, pochwała eugeniki itp. Co ciekawe, choć Potrzebowski często przywołuje Heroiczną wspólnote narodu, to ani razu nie wspomina o tym, że Stachniuk niemal w pełni akceptuje teorię imperializmu rozwijaną przez Włodzimierza Lenina i Różę Luksemburg, o czym Stachniuk pisze wprost w przedmowie do wspomnianej książki. Ponadto, autor Dziejów bez dziejów rozróż- 
Stachniuk writes directly in the foreword to that book. In addition, the author of Dzieje bez dziejów distinguishes on cultural and backward-cultural socialism in Człowieczeństwo i kultura, giving the example of the economic model of the USSR.

Does this mean that Stachniuk was a Marxist? No, it doesn't. Does this mean that Stachniuk was delighted with Marx? No, it doesn't. This simply means that he used certain elements of his theory. Although the movement Zadruga undoubtedly had a nationalistic character, defining it unambiguously as a "right", without giving a precise definition of this term and without giving any kind of arguments is at least highly debatable. We should mention the fact that history knows more than one example of a left-wing nationalism - such as Irish or Basque. Nationalism and right wing are not identical concepts.

The richness of Zadruga thought is among others in the fact that it can not be clearly attributed either to the left or to the right - the movement had elements of both right-wing and left-wing. Any attempt to pigeonhole this movement as clearly left-wing or right-wing inevitably leads to distortions and falsifications.

It also seems that S. Potrzebowski in describing predecessors of Zadruga completely ignored Stanislaw Brzozowski, who after all had a huge impact on Stachniuk's ideas. The category of "work" by Brzozowski is very close to the category of "culture" by Stachniuk. Both are central concepts that express the creation of intersubjective reality through "processing" energy of elements. A critical approach to traditionally understood Polishness, the Jesuits, the Ro- nia socjalizm na kulturowy i wspakulturowy w Człowieczeństwie i kulturze, podając za przykład model gospodaczy ZSRR.

Czy to oznacza, że Stachniuk był marksistą? Nie. Czy oznacza to, że Stachniuk był zachwycony Marksem? Nie. Oznacza to po prostu, że używał pewnych elementów jego teorii. Choć ruch Zadrugi bez wątpienia miał charakter nacjonalistyczny, to określanie go jednoznacznie mianem „prawica” bez podania dokładnej definicji tego terminu i bez podania rzeczowych argumentów na poparcie tezy jest co najmniej mocno dyskusyjne. Wspomnieć należy chociażby to, że historia zna niejeden przykład lewicowego nacjonalizmu - jak choćby irlandzki czy baskijski. Nacjonalizm i prawica nie są pojęciami tożsamymi.

Bogactwo myśli zadrużnej polega m.in. na tym, że nie da się go jednoznacznie przypisać ani do lewicy, ani do prawicy ruch ten miał bowiem elementy zarówno prawicowe, jak i lewicowe. Jakakolwiek próba szufladkowania tego ruchu jako jednoznacznie lewicowego czy prawicowego prowadzi nieuchronnie do zniekształceń i przekłamań.

Zdaje się również, że Stanisław Potrzebowski w opisywaniu poprzedników Zadrugi zupełnie pominął Stanisława Brzozowskiego, który przecież wywarł ogromny wpływ na myśl Jana Stachniuka. Kategoria „pracy” Brzozowskiego jest bardzo bliska kategorii „kultury” Stachniuka. Oba są centralnymi pojęciami, które wyrażają tworzenie intersubiektywnej rzeczywistości poprzez „przetwarzanie” energii żywiołów. Krytyczne podejście do tradycyjnie pojmowanej polskości, do jezuitów, do romantyków, wymieszanie 
mantics, mixing nationalism with socialist and syndicalist threads - all these threads occurring in the author of Legenda Młodej Polski (The Legend of Young Poland) had a significant and pronounced influence on the thought of Zadruga. Brzozowski is still often cited by both Stachniuk and Wacyk.

Stanisław Potrzebowski clearly states in his book that Marxism is not a philosophy, but a "pseudoscience" and "sophisticated demagogy and masked ideology of genocide" . Marxism can be assessed differently, positively or negatively, but it is impossible to deny that Marxism is generally classified as one of the currents of philosophy, regardless of what private opinion we have of it. It is common knowledge that communism (whose philosophical base is undoubtedly Marxism) is widely recognized as a criminal ideology. However, intellectual honesty requires to make a distinction between Marxism and communism. One results from the other - of course, but they are not identical. Marxism-Leninism is different from the Western Marxism. What is acceptable in a political pamphlet (simplifications, or rhetorical devices) is out of place in a book of a scientific nature. And that's the main problem in the publication. There are also a lot of non-substantive and of huge emotional charge expressions. Here are some examples:

- $[\ldots]$ Balicki fights advanced decadence rampant in the society. Initially a decadent does not distinguish friend from foe, he does not understand what is happening around him, does not understand the world. Then he ingratiates with the enemy,

\footnotetext{
${ }^{5}$ S. Potrzebowski, op. cit., s. 103.
}

nacjonalizmu z wątkami socjalistycznymi i syndykalistycznymi - te wszystkie wątki występujące u autora Legendy Młodej Polski wywarły znaczący i wyraźny wpływ na myśl Zadrugi. Brzozowski jest przecież cytowany często zarówno przez Stachniuka, jak i Wacyka.

Stanisław Potrzebowski jednoznacznie stwierdza w swej książce, że marksizm nie jest filozofią, tylko „pseudonauką" $\mathrm{i}$ „wyszukaną demagogią i zamaskowaną ide-

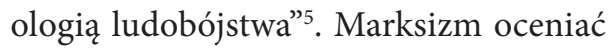
można różnie, pozytywnie lub negatywnie, niemniej niepodobna przeczyć, że marksizm jest powszechnie zaliczany do jednego z nurtów filozofii, niezależnie od tego, jaką mamy prywatnie o nim opinię. Jest rzeczą powszechnie wiadomą, iż komunizm (którego bazę filozoficzną stanowi niewątpliwie marksizm) jest powszechnie uznany za ideologię zbrodniczą. Jednakże, intelektualna uczciwość nakazuje dokonać rozróżnienia między marksizmem a komunizmem. Jedno $z$ drugiego wynika oczywiście, ale jedno z drugim nie jest tożsame. Czym innym jest marksizm-leninizm, a czym innym zachodni marksizm. To co dopuszczalne w broszurze politycznej (uproszczenia czy chwyty retoryczne) jest nie na miejscu w książce o charakterze naukowym. I w tym tkwi główny problem w publikacji. Występuje w niej również sporo niemerytorycznych zwrotów i wyrażeń o sporym ładunku emocjonalnym. Oto niektóre przykłady:

- [...] tępi Balicki zaawansowaną dekadencję szerzącą się w społeczeństwie. Początkowo dekadent nie odróżnia przyjaciela od

${ }^{5}$ S. Potrzebowski, op. cit., s. 103. 
repels a friend. Finally, he works deliberately to his own detriment, as in the case of colonization of Europe by Afro-Asians because he is under the influence of, crammed into his mind, progressiveness, political correctness, backward-values, etc ${ }^{6}$.

- [...] Emmanuel Milingo, archbishop of Lusaka, capital of Zambia [...]. In the years 1983-1999 he officiated at the Vatican, rapped at festivals and evangelized the stadiums to the delight of the Italian mohair berets ${ }^{7}$.

- As when Stachniuk lived, now in the same way most of the people live from day to day, mindlessly feeding on stultifying programs on television, or playing online or living just to have fun. As formerly, the saying that "every [Polish Catholic] must drink" is popular'.

- The hierarchy of Catholic Church, full of pride and arrogance, celebrates arrogantly1050 years of infecting the living organism of the nation with germs of Judeo-Christianity9.

- The modern, so-called professional sport [...] has become an important means of propaganda to mongrelize nations ${ }^{10}$.

The aim of the research work is not instructing the reader in a moralistic way. Surprising that S. Potrzebowski, who is after all a Ph.D., uses this type of discourse at work, which claims to be scientific. Something that could be a really great book has been mutilated in this way with quite brusque language. What a pity!

In conclusion, despite some defects, the book is a good work for someone interested in the history of Zadruga and its thoughts. This organization tried to draw attention to the need for the mate- wroga, nie pojmuje, co wokół niego dzieje się, nie ogarnia świata. Następnie przymila się do wroga, a przyjaciela odpycha. Ostatecznie działa rozmyślnie na swą szkodę, jak choćby w wypadku zasiedlania Europy afroazjatami, bo tak nakazują wtłoczone mu postępowość, polityczna poprawność, wspakwartości itd. ${ }^{6}$

- [...] Emanuel Milingo, arcybiskup Lusaki stolicy Zambii [...]. W latach 1983-99 urzędował on w Watykanie, rapował na festiwalach i ewangelizował na stadionach ku zachwycie włoskich moherowych beretów ${ }^{7}$.

- Jak za życia Stachniuka, tak i obecnie większość ludzi żyje z dnia na dzień, bezmyślnie karmiąc się ogłupiającymi programami $\mathrm{w}$ telewizji, lub grając $\mathrm{w}$ internecie, lub żyjąc aby tylko się bawić. Jak dawniej jest popularne powiedzonko, że „każdy [Polak-katolik] musi se wypić".

- 1050 lat zarażania żywego organizmu narodu zarazkami judachrystianizmu obchodzi arogancko pełna pychy hierarchia $\mathrm{KK}^{9}$.

- Współczesny, tzw. zawodowy, sport [...] stał się ważnym środkiem propagandy bastardyzacji narodów ${ }^{10}$.

Celem pracy naukowej nie jest moralizatorskie pouczanie czytelnika. Dziwi to, że Potrzebowski, który ma przecież tytuł doktora, stosuje tego typu dyskurs w pracy, która rości sobie prawo do naukowości. Coś, co mogło być naprawdę świetną książką, zostało w powyższy sposób okaleczone przez dość obcesowy język. A szkoda!

Podsumowując, pomimo niejednej wady, książka stanowi dobrą pozycję dla kogoś zainteresowanego historią Zadrugi i jej myśli. Ta zaś starała się zwrócić uwa-

\footnotetext{
6 Ibidem, s. 21.

Ibidem, s. 141.

8 Ibidem, s. 149.

9 Ibidem, s. 156.

${ }^{10}$ Ibidem, s. 163.
} 
rial development of Poland and its full potential, which was and continues to be necessary if we consider our geopolitical situation and difficult history. Contesting traditionalistic National Democracy and ONR nationalism, in which neo-medieval accents has still been resonating strongly up to today, despite all its shortcomings Zadruga circled new horizons. Therefore, a new book by S. Potrzebowski, while maintaining a critical distance to some of the author's statements, however, is a good introduction to such an important topic. It is already the fifth textbook development of Stachniuk's thought ${ }^{11}$ that still can be used to stimulate rational thinking about the state, nation and their material bases as indispensable condition for the preservation of sovereignty between Germany and Russia.

${ }^{11}$ See also: B. Grott, Religia, cywilizacja, rozwój: wokót idei Jana Stachniuka, Kraków 2003; J. Skoczyński, Neognoza polska, Kraków, 2004; R. Siedliński, Człowiek, mit, kultura: myśl społeczno-historiozoficzna Jana Stachniuka, Toruń 2008. gę na konieczność materialnego rozwoju Polski i całego jej potencjału, co było i nadal jest niezbędne, zważywszy na nasze położenie geopolityczne i trudną historię. Zadruga, kontestując tradycjonalistyczny nacjonalizm endecki i onrowski, w którym jeszcze do dzisiaj mocno pobrzmiewają neomediewalne akcenty, mimo wszystkich swoich braków zakreśliła nowe horyzonty. Dlatego nowa książka Potrzebowskiego, przy zachowaniu krytycznego dystansu do niektórych wypowiedzi autora, stanowi jednak dobre wprowadzenie do ważnego przecież tematu. Jest ona piątym już książkowym opracowaniem myśli Stachniuka ${ }^{11}$, która przecież nadal może służyć do stymulowania racjonalnego myślenia o państwie, narodzie i ich materialnych podstawach jako niezbywalnym warunku zachowania suwerenności pomiędzy Niemcami a Rosją.

Paweł Bielawski* Jagiellonian University, Poland / Uniwersytet Jagielloński, Polska

11 Poza opracowaniami Potrzebowskiego zob. jeszcze B. Grott, Religia, cywilizacja, rozwój: wokół idei Jana Stachniuka, Kraków 2003; J. Skoczyński, Neognoza polska, Kraków 2004; R. Siedliński, Człowiek, mit, kultura: myśl społeczno-historiozoficzna Jana Stachniuka, Toruń 2008.

\footnotetext{
* Correspondence address: Instytut Religioznawstwa, Uniwersytet Jagielloński, ul. Grodzka 52, 31-044
} Kraków, Polska, e-mail: pawel.bielawski@doctoral.uj.edu.pl. 